\title{
IDENTIFICATION OF FACILITIES AND INFRASTRUCTURE FOR UNITED FOREST MANAGEMENT: A CASE STUDY OF BENGALON KPHP IN KUTAI TIMUR DISTRICT, INDONESIA
}

\author{
Aliri $^{* 1,4}$, Sarjono Mustofa Agung ${ }^{2}$, Hartanto Sigit ${ }^{2}$, Juremi $^{3}$ \\ ${ }^{1}$ Kutai Timur College of Agriculture, Indonesia \\ ${ }^{2}$ Faculty of Forestry, Mulawarman University, East Kalimantan, Indonesia \\ ${ }^{3}$ Faculty of Agriculture, Mulawarman University, East Kalimantan, Indonesia \\ ${ }^{4}$ Postgraduate Program of Forestry Science, Mulawarman University, Indonesia \\ *E-mail: aliri.stiperkutim@gmail.com
}

\begin{abstract}
This research was conducted at one of the KPHs in East Kutai Regency, namely, KPHP Bengalon which includes Karangan, Kongbeng, Bengalon, Muara Wahau, Rantau Pulung, Batu Ampar, Telen, Muara Bengkal, Long Mesangat, Busang, Kongbeng and Sangata Selatan Districts. This study generally aims to analyze the availability of facilities and infrastructure to support the achievement of the Forest Management Unit development, using the case study of KPHP Bengalon in East Kutai Regency. Analysis of the availability of facilities and infrastructure aims to determine whether the facilities and infrastructure owned by the Bengalon KPHP are appropriate with the ideal requirements for an FMU. To analyze the aspects of the availability of facilities and infrastructure at KPHP Bengalon, the content analysis method and the interview method were used. The results of the analysis showed that the availability of facilities and infrastructure at KPHP Bengalon was still very minimal for the operation of an FMU. For the manager of the Bengalon $\mathrm{KPH}$ to encourage the government to immediately facilitate facilities and infrastructure. With the lack of facilities and infrastructure of the Bengalon KPHP, it has an impact on the obstruction of work programs that have been planned by the KPHP Bengalon management.
\end{abstract}

\section{KEY WORDS}

KPHP, forest processing, facilities, infrastructure, Bengalon.

In accordance with the constitutional mandate of all forests in the territory of the Republic of Indonesia, including the natural resources contained therein, shall be controlled by the State to be utilized maximally for the welfare of the people. In the framework of this control, the state gives authority to the Government, which is the personification of the state to regulate and manage everything that is related to forests. One of several forest management efforts to obtain maximum benefit for the welfare of the people is through the development of Forest Management Units / FMUs (Suprianto, 2012).

Castaneda (2000) defines an FMU as a forest management unit whose area has been defined with clear boundaries, where most of the area is covered by forest, is managed for the long term, and has a number of clear objectives that are set out in a forest management plan. According to (Kartodihardjo and Suwarno, 2014), the FMU development process is actually a process of institutional change, where in the process of institutional change there are several main points of fundamental change which become its basic philosophy, namely: (a) Value changes and methods think; (b) Changes in the jurisdiction boundary; (c) Real output-based management; and (d) Increased transparency and accountability.

FMU development as an operational unit is a mandate of Forestry Law No. 41 of 1999, which seeks to streamline and streamline forestry development by separating the management agencies in the autonomous administrative area (Forest Service) from the management agency at the site level (Management Unit / KPH) (Sardjono, 2009; Nugroho, 2013).

In supporting the creation of a professional FMU, it is necessary to provide adequate facilities and infrastructure. Minister of Forestry Regulation Number. P.41 / Menhut-II / 2011 
concerning Standards for Facilitation of Facilities and Infrastructure for Model Protected Forest Management Units and Model Production Forest Management Units, is explained in article 2 paragraph 1 that facilitating the facilities and infrastructure of Model KPHL and Model KPHP is provided by the government in encouraging the operation of KPHL and $\mathrm{KPHP}$ in the field. Further in paragraph 3 it is explained, the facilitation of facilities and infrastructure for the KPHL Model and KPHP Model as described in article 2 paragraph (I), includes office buildings, operational vehicles, office equipment, and operational equipment. Furthermore, it is explained, the facilitation of operational vehicles as referred to includes: a. four-wheeled vehicles; b. two-wheeled vehicles; and / or c. water vehicle. The office equipment facilitation as referred to includes: a. Tables and chairs; b.office wardrobe; and c. office electronic equipment. The operational equipment facilitation as referred to includes: a. communication tool; b. computer software; c. computer hardware; and D. survey equipment

Regarding the fulfillment of FMU operational facilities and infrastructure needs, the Directorate General of Forestry Planning (2014) states, identifying FMU facilities and infrastructure as presented in Table 1 below:

Table 1 - Identification of FMU Facilities and Infrastructure

\begin{tabular}{|c|l|c|}
\hline No. & Types of Facilities and Infrastructure & Volume \\
\hline (a) & (b) & (c) \\
\hline \multirow{2}{*}{1.} & Office building & 1 unit \\
\cline { 2 - 3 } & KPH Office & $\mathrm{pm}$ \\
\hline \multirow{2}{*}{2.} & KPH Resort Office & 1 unit \\
\cline { 2 - 3 } & Means of transportation & $\mathrm{pm}$ \\
\cline { 2 - 3 } & 4 wheeled vehicles & $1 \mathrm{unit}$ \\
\cline { 2 - 3 } & 2 wheeled vehicles & $\mathrm{pm}$ \\
\hline 3. & Water Vehicles (Speed Boat) & $\mathrm{pm}$ \\
\hline 4. & Office equipment & $\mathrm{pm}$ \\
\hline 5. & Survey Equipment & $\mathrm{pm}$ \\
\hline 6. & Mapping Equipment & $\mathrm{pm}$ \\
\hline 7. & Supporting facilities for forest management activities & $\mathrm{pm}$ \\
\hline 8. & Supporting infrastructure for forest rehabilitation activities & $\mathrm{pm}$ \\
\hline 9. & Making forest management facilities & \\
\hline
\end{tabular}

Source: Directorate General of Forestry Planning (2014).

East Kutai Regency itself has forests with an area of $\pm 2,198,354 \mathrm{Ha}$, divided into several functions which include protection functions, conservation functions and production functions. The details are based on their function, namely conservation areas which are divided into Nature Reserve areas and Nature Conservation Areas with an area of $\pm 219,385$ $\mathrm{Ha}$, Protected Forests $\pm 270,726 \mathrm{Ha}$, Limited Production Forests covering an area of $868,778 \mathrm{Ha}$, and Fixed Production Forests of 839,455 Ha (BPS Kutim, 2014).

The Bengalon Production Forest Management Unit (KPHP) is one of the KPHs located in East Kutai Regency, East Kalimantan Province covering an area of $\pm 688,672 \mathrm{Ha}$. Geographically it is located between $0^{\circ} 20^{\prime} 9.01$ "N-1 ${ }^{\circ} 41^{\prime} 7.07^{\prime \prime} \mathrm{NL}$ and $116^{\circ} 41^{\prime} 44.02$ "BT$117^{\circ} 50^{\prime} 36.9^{\prime \prime}$ BT, which was formed through the Decree of the Minister of Forestry No: SK.674 / Menhut-II / 2011 concerning the Determination of KPHL and KPHP Areas in East Kalimantan Province. The institution is in the form of a Regional Technical Implementation Unit (UPTD) based on the Regulation of the Governor of East Kalimantan No: 101 of 2016 concerning the Formation and Organizational Structure of the UPTD at the East Kalimantan Provincial Forestry Service (UPTD KPHP Bengalon 2018).

In general, this research aims to analyze the availability of facilities and infrastructure to support the achievement of the development of a Forest Management Unit using the case study of KPHP Bengalon in East Kutai Regency. Expected results; a. The government, in this case the Ministry of Environment and Forestry and the Provincial Government of East Kalimantan, as input and reference for building professional FMUs; $b$. The management of 
KPHP Bengalon and other related parties in East Kutai Regency, in building effective management, especially in forest areas or FMU areas.

\section{MATERIALS AND METHODS OF RESEARCH}

Research that focuses on the issue of FMU "professionalism", especially on the situation and conditions of East Kalimantan has never been conducted before. Therefore, this research requires a case to be studied and for that purpose one of the KPHs in East Kutai Regency is taken, namely KPHP Bengalon.

The materials and equipment used in this study are as follows:

- Area location map;

- Regulations / policies from the Government (primarily the Ministry of Forestry) relating to research and regional development policies/ Regional Regulations;

- The plan to build the Bengalon KPHP from the East Kutai Forest Service;

- List of questions for informants (key and community leaders, adat heads, and village heads);

- Stationery, to record observations and results of consultations and in-depth interviews with community groups and the Implementing Unit;

- Computers and accessories are used for data processing and report preparation.

The objects in this study consist of:

- Central Government / Ministry of Forestry Regulations and Policies concerning FMU development and management;

- East Kutai Regency Goverment regulations and policies relating to the development and management of FMUs;

- The document of the Bengalon KPHP development activity program from the East Kutai Forest Service;

- Officials / officials from related institutions such as the Forestry Service, Environmental Agency, Regional Development Planning Agency and UPTD Planology.

This study combines the documentation study method from various secondary data sources and the direct method, namely the collection of primary data in the field with interview techniques, structured and unstructured interviews (through questionnaires) and field observations. at the research location with the intention of validating secondary data.

The data that has been collected is then analyzed as follows:

Analysis of the draft Bengalon KPHP management plan.

- The management plan analysis is used to analyze in clarifying, understanding, managing and responding to problems in the development of the Bengalon KHPH in East Kutai Regency. To analyze this situation, the content analysis method is used;

- Analysis of the availability of facilities and infrastructure at the KPHP Bengalon;

- Analysis of the availability of facilities and infrastructure aims to determine whether the facilities and infrastructure owned by the Bengalon KPHP are in accordance with the ideal requirements for an FMU. To analyze aspects of the availability of facilities and infrastructure at KPHP Bengalon, the content analysis method and interview method are used.

\section{RESULTS AND DISCUSSION}

Geographically, the Bengalon Production Forest Management Unit (KPHP) is located between $0{ }^{\circ} 20^{\prime} 9.01$ "N-1 ${ }^{\circ} 41^{\prime} 7.07^{\prime \prime} \mathrm{NL}$ and $116^{\circ} 41^{\prime} 44.02$ "BT-117 ${ }^{\circ} 50^{\prime} 36.9 "$ East Longitude. While hydrologically the Bengalon KPHP management area is included in 6 (six) Watersheds (DAS), namely the Mahakam Watershed, Berau Watershed, Bengalon Watershed, and Karangan Watershed, Sangatta Watershed and Tabalar Watershed. Meanwhile, administratively KPHP is located in three regencies namely Berau, Kutai Kertanegara and Kutai Timur. However, most of the KPHP area $(78.7 \%)$ is in the 
administrative area of the East Kutai Regency Government and covers 12 districts, namely: Batu Ampar, Bengalon, Busang, Karangan, Kaubun, Kongbeng, Long Masangat, Muara Bengkal, Muara Wahau, Rantau Pulung, Sangatta Selatan, and Telen.

The availability of facilities and infrastructure to support the implementation of the main tasks and functions of FMU management is an important part of the implementation of these main tasks and functions. Through Regulation of the Minister of Forestry Number: P.41 / Menhut-II / 2011 concerning Standard Facilities and Infrastructure for Model Protected Forest Management Units and Model Production Forest Management Units, it is explained that, in article 2 paragraph 1 , it is stated that the facilitation of means and infrastructure for Model $\mathrm{KPHL}$ and Model KPHP provided by the Government in order to encourage the operation of $\mathrm{KPHL}$ and KPHP in the field, hereinafter paragraph 2 mentions the facilitation of KPHL Model and Model KPHP facilities other than by the Government as referred to in paragraph (1) can be provided by the Regional Government.

KPHP Bengalon it self is an institution that was only formed in 2016. Based on the results of field observations and interviews regarding the availability of facilities and infrastructure for UPTD KPHP Bengalon, currently it is still borrowing and using an office building belonging to the East Kutai district government, for operational vehicles alone there is 1 (one) vehicle. 4-wheeled service, while 2-wheeled vehicles are not yet available. Office equipment and supplies that are available at KPHP Bengalon are computer PCs, printers, air conditioning machines, work tables/ chairs, filing cabinets, LCD projectors.

The existing facilities and infrastructure are deemed inadequate for an UPTD KPHP. This requires the facilitation of facilities and infrastructure, such as procurement / construction of buildings and vehicles for field operations. Support for electricity, water and communication networks, including computers and the internet, which are sufficient to support daily forest management activities. Work equipment also needs to be prepared, including radio communications, compasses, GPS, forest security facilities (patrol vehicles, handcuffs, ropes, clothing accessories. forest and others) including forest and land fire suppression equipment. Drones can also be budgeted to facilitate air monitoring activities. It is necessary to establish the standard and infrastructure in each FMU properly so that field officers working in the middle of the forest can carry out their duties properly. The facilities and infrastructure needs at KPHP Bengalon that need to be completed for the 2018-2027 period are as listed in Table 2.

Table 2 - Priority Fulfillment of Infrastructure Facilities and Equipment of the Nominating KPHP

\begin{tabular}{|c|c|c|c|}
\hline No & Sara's Infrastructure Needs and Equipment & Amount & Information \\
\hline (a) & (b) & (c) & (d) \\
\hline A. & Facilities and infrastructure & & \\
\hline 1. & Construction of a new KPH office & 1 unit & Sangatta \\
\hline 2. & Information Center Development & 1unit & Adjoining the Bengalon KPHP Office \\
\hline 3. & Procurement of wheeled vehicles 4 & 4 unit & For KKPH and Operations \\
\hline 4. & Procurement of wheeled vehicles 2 & 4 unit & Each Section \\
\hline 5. & KPH Office Facilities & 1Package & Office Completeness \\
\hline 6. & Fire extinguisher storage warehouse & 1unit & Each RPH 1unit \\
\hline 7. & Satellite internet network (V-Sat) & 1Package & Respective RPH and head office \\
\hline $\mathrm{B}$ & Office equipment & & \\
\hline 1. & Computer & 10 unit & \\
\hline 2. & Notebook & 10unit & \\
\hline 3. & Typewriter & 2unit & \\
\hline 4. & A3 printer & 6unit & \\
\hline 5. & Printer & 6unit & \\
\hline 6. & Scanner & 6unit & \\
\hline 7. & Plotter & 1unit & \\
\hline 8. & UPS/Stabilizer & 10unit & \\
\hline 9. & LCDProyektor & 3unit & \\
\hline 10. & Digital pocket camera & 3unit & \\
\hline 11. & DSLR Camera & 3unit & \\
\hline 12. & Handycam & 3unit & \\
\hline 13. & VoiceRecorder & 4unit & \\
\hline 14. & Facsimile machine & 1unit & $\mathrm{KPH}$ \\
\hline $\mathrm{C}$ & Forestry Equipment & & \\
\hline 1. & GPS & 8unit & \\
\hline
\end{tabular}




\begin{tabular}{|c|c|c|c|}
\hline 2. & Compass & 8unit & \\
\hline 3. & Clinometer & 8unit & \\
\hline 4. & Phi Band & 8unit & \\
\hline 5. & Roll Meter & 8unit & \\
\hline 6. & Laser Meter & 8unit & \\
\hline 7. & Hagameter & 8unit & \\
\hline 8. & Binokuler & 4unit & \\
\hline 9. & Monokuler & 4unit & \\
\hline 10. & Setphone & 4unit & \\
\hline 11. & Radio Handy Talkie(HT) & 3unit & \\
\hline 12. & HandyTalkie & 10unit & \\
\hline 13. & Pelbet & 10unit & \\
\hline 14. & Forestry Police Equipment & PM & as needed \\
\hline 15. & $\begin{array}{l}\text { Management Equipment for Timber Forest Products and } \\
\text { Non-Timber Forest Products }\end{array}$ & PM & as needed \\
\hline 16. & Herbarium Equipment & PM & as needed \\
\hline $\mathrm{D}$ & First aid kit & & \\
\hline 1. & Medicines, etc. & PM & as needed \\
\hline $\mathrm{E}$ & Fire Fighting Equipment (Brig dalkar KPHP Bengalon) & & \\
\hline 1. & Fire Operational Vehicles Fire & 5 unit & \\
\hline 2. & Tanker & 4 unit & \\
\hline 3. & Two-wheeled vehicle & 10 unit & \\
\hline 4. & Megaphone & 1unit & \\
\hline 5. & Car radio & 10 unit & Installed in operational cars and tank cars \\
\hline 6. & Genset & 2unit & \\
\hline 7. & Water Pump Machine & 2unit & $\mathrm{KPH}$ \\
\hline 8. & Fire hose & 25 unit & $\mathrm{KPH}$ \\
\hline 9. & Nozzle & 3unit & \\
\hline 10. & Folding water tank & 3unit & \\
\hline 11. & Chain saw & 1unit & \\
\hline 12. & Flapper & 10unit & $\mathrm{KPH}$ \\
\hline 13. & Boots & 10 pairs & \\
\hline 14. & Helmet & 10unit & $\mathrm{KPH}$ \\
\hline 15. & Machete & 10unit & $\mathrm{KPH}$ \\
\hline 16. & Hoe rakes & 3unit & $\mathrm{KPH}$ \\
\hline 17. & Sharp rakes & 6unit & \\
\hline 18. & One-eye ax & 4 unit & \\
\hline 19. & Two-function ax (Pulaski) & 4 unit & \\
\hline 20 & Shovel & 6 unit & \\
\hline 21 & Back pump & 10unit & \\
\hline 22 & Gepyok & 8 unit & \\
\hline 23 & Torch ignition drops & 1unit & \\
\hline 24 & $\begin{array}{l}\text { Personnel equipment (hats, masks, goggles, peples, } \\
\text { whistles, etc.) }\end{array}$ & 13 unit & \\
\hline
\end{tabular}

Source: UPTD KPHP Bengalon, 2018.

\section{CONCLUSION}

The availability of facilities and infrastructure at KPHP Bengalon is still very minimal for the operation of an FMU. For this reason, efforts are needed for the managers of the Bengalon $\mathrm{KPH}$ to encourage the government to immediately facilitate facilities and infrastructure. The lack of facilities and infrastructure for the KPHP Bengalon has an impact on the obstruction of the work programs that have been planned by the KPHP Bengalon management.

\section{REFERENCES}

1. BPS Kutim. 2014. East Kutai in Numbers. East Kutai Central Bureau of Statistics.

2. Castaneda F. 2000. Why national and forest management unit level criteria and indicator for sustainable management of the dry forest in Asia. in: Cheng TL, Durst PB, editors. Development of national-level criteria and indicator for sustainable management of the dry forest in Asia: background paper. Rap Publication, Bangkok, Thailand (TH). 1-22.

3. Ministry of Forestry. 2014. FMU Development Policies and Priorities. Presented at the Discussion on the Finalization of the RPI for the 2015-2019 Period. Jakarta. 
4. Kartodihardjo H, Suwarno E. 2014. Mainstreaming Forest Management Units (KPH) in Forestry Licensing Policy and Implementation. Jakarta (ID): Directorate of Forest Area Management and Preparation of Forest Area Utilization Areas, Directorate General of Forestry Planning.

5. Regulation of the Minister of Forestry Number: P.41 / Menhut-II / 2011 concerning Standard Facilities and Infrastructure for Model Protected Forest Management Units and Model Production Forest Management Units.

6. Suprianto. T. 2012. Forest Management Unit towards Sustainable Forest Utilization. BTNLL. Central Sulawesi.

7. Sardjono M.A, and Nugroho, B. 2013. Financial Management Patterns of Regional Public Service Bodies towards KPH Independence. Directorate of Forest Area Management and Preparation of Forest Area Utilization Areas, Directorate General of Forestry Planning. Jakarta.

8. UPD KPHP Bengalon. 2018. Long Term Forest Management Plan (RPHJP) of Bengalon KPHP 2018-2027. 